\title{
REVERSAL OF MISFORTUNE
}

\author{
Alternative culture.
}

\section{BY J. W. ARMSTRONG}

$\mathrm{T}$ he philosophers claim that knowing you're going to be hanged in the morning focuses the mind wonderfully. This is not completely true. Also, I suspect that the philosophers do not speak from first-hand experience.

As I waited, an hour before my execution, my unfocused mind ranged freely - jumping from event to event - over how this had come to be.

It started five years ago. My colleagues and I were working to resolve a paradox in theoretical physics related to the many-worlds interpretation of quantum mechanics - the idea that the Universe bifurcates every time any decision is made, leading to a multiverse of alternate realities. Our breakthrough was, in retrospect, obvious. Without going into detail, we demonstrated that many-worlds is true, but with a twist: most decisions are unimportant and just blur the timeline. True bifurcation does not occur for every decision; rather the multiverse branches only on some decisions, perhaps, by definition, the 'consequential' ones.

But we went further. We showed that information leaks between nearby timelines. You can't visit a reality-that-mighthave-been, but you can use its leaked information to glimpse (eavesdrop on?) the consequences of decisions you might have made differently. In addition to the physics, the personal possibilities were fascinating. Should you have married your first love? Should you have accepted that careerchanging job offer? Should you have had children with the partner you did? Should you have had children at all?

We should have left it at that - establishing that leaked information from other timelines was detectable in principle. But I had an insight about how, in a practical way, the leaked information could actually be detected. We were almost giddy, and published quickly; I was the first author of Fossman et al..

Academic accolades followed immediately, including a very fast-track Nobel. The detector - the media dubbed it the 'Fossman device' - also went from theory to practice

$\rightarrow$ NATURE.COM Follow Futures: @ @NatureFutures f go.nature.com $/ \mathrm{mtoodm}$ very quickly. At first the cost was enormous and the 'range' of the detector was severely limited by the technology - only entities with the resources of a government could afford it, and only the nearest timelines could be detected. Militaries were interested, of course. Surprisingly to me, organized religions brought massive

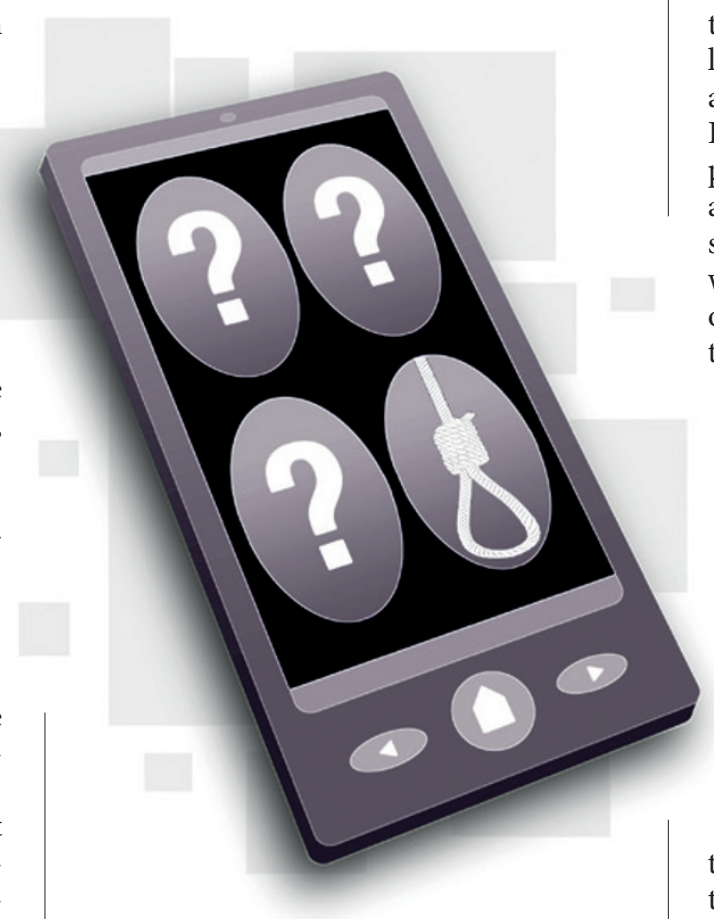

resources to bear and were also early adopters. But the technology improved swiftly, the cost plummeted, and the number of alternate timelines accessible increased markedly. Soon corporations, presumably for some competitive advantage, used the technology. Then wealthy individuals could search their alternate timelines. Finally the technology was commodified, cell-phone-like, and was available to everyone.

When it got to that point - where any individual could afford to search thousands of alternate histories - it became an explosive social phenomenon.

The evidence mounted slowly at first. But as more and more people searched their alternate realities it became clear: the world we have fashioned - the Universe created by our collective decisions - was not 'average' compared with what could-have-been. No ... rather, our collective decisions were abysmally poor.

Not everyone's, of course - there were examples of people having made excellent life choices. But the average decisions individuals made in our Universe were substantially inferior to those that could have been made - and those that actually were made in our alternate universes.

The initial public reaction was shock. TV chat shows, ostensibly trying to put our world in a multiverse perspective, trotted out philosophers, physicists and theologians to argue determinism, causality and free will in varying levels of sophistry. Late-night infomercials - for four easy payments of $\$ 39.95$ - flogged products and services to absolve guilt: your life decisions, bad though they might have been, were not your fault; rather you were a victim of randomness, malefic supernatural entities or whatever else would sell the product. Public shock morphed to sullen bewilderment - and then, quickly, to rage. People were angry and responded in the timehonoured human way: they looked for someone else to blame for their troubles. As the inventor of the technology that had revealed humanity's collective bad judgement, I was the obvious choice.

A mob mentality ensued and the government issued a Writ of Inquisition. I was tried and convicted of 'crimes against humanity'. The conviction was swift - perhaps because my defence team, too, had examined their alternate lives, hated themselves (and me for allowing them this knowledge) and put up only a token effort. I was sentenced to hang by the neck until dead.

Which brings us to now, minutes before my execution, and the focusing of minds ...

I'd read someplace that it is important to be stoic at such times. As I was marched to the gallows, seeing the hangman's noose, I nonetheless swallowed hard and had an uncontrollable desire to scratch my neck. I was saved from the ignominy of this gesture only because my hands were tied behind my back.

But in fact I can say, as I slowly mounted the scaffold, that I deported myself absolutely as well as could be hoped. You see I, too, had used the Fossman device, in this case to look at my endgame in other universes - and the alternatives there were very unpleasant indeed. As the noose was fitted around my neck, I took what comfort I could in knowing that I was about to depart the best of all possible worlds.

J. W. Armstrong works at a large laboratory in Southern California. The technology described here is fiction. Really. And if it isn't, none of this applies to us. 